\title{
Prevention of natural grassland invasion by Eragrostis plana Nees using ecological management practices ${ }^{1}$
}

\author{
Telmo Focht ${ }^{2}$, Renato Borges de Medeiros ${ }^{3}$
}

\author{
${ }^{1}$ Financed by CNPq, CAPES and Sindicato Rural de Dom Pedrito. \\ ${ }^{2}$ Departamento de Ecologia, Instituto de Biociências, UFRGS, Caixa Postal 15100, CEP: 90001-970, Porto Alegre, RS, Brazil. \\ ${ }^{3}$ Departamento de Plantas Forrageiras e Agrometeorologia, Faculdade de Agronomia, UFRGS.
}

\begin{abstract}
The objective of this research was to evaluate the effects of different types of disturbance on the ability of the natural grassland to avoid the invasion of Eragrostis plana Nees (South African lovegrass). The experiment was carried out in Dom Pedrito, Rio Grande do Sul, Brazil, in an area free of South African lovegrass, from Feb. 2004 to Apr. 2007. The treatments were: 1) grassland management regimes: exclusion; low grazing intensity (rotational grazing), $\pm 10 \mathrm{~cm}$; and high grazing intensity (continuous grazing), $\pm 5 \mathrm{~cm} ; 2$ ) initial levels of soil disturbance: high grassland, $\pm 10 \mathrm{~cm}$; low grassland, $\pm 5 \mathrm{~cm}$ height; and low grassland with scarified soil; 3) fertilization regimes: without fertilization; phosphorus; and nitrogen. The experimental design was a split-split-plot type in complete blocks, with three replicates. Three winter cultivated species - Trefoil repens L., Lotus corniculatus L., Lolium multiflorum Lam. and South African lovegrass - were sown in 54 split-splitplots (split-plots: low grassland, and low grassland with scarified soil). The other 27 split-split-plots (split-plots: high grassland) were sown only with South African lovegrass. The grassland height, plant number of South African lovegrass, grassland dry mass and photosynthetic active radiation intercepted (FARint) at the soil level were recorded. The fertilization regimes did not influence the South African lovegrass plant number. The initial levels of soil disturbance and grassland management regimes influenced the invasion of South African lovegrass. The invasion was favored by the lower grassland height and lower forage mass, higher intensity of the soil disturbance, and higher FARint due to the continuous grazing. On the contrary, higher grassland height, higher forage mass, lower soil disturbance and lower FARint, associated with rotational grazing or exclusion, showed higher potential to control the invasion of South African lovegrass in the natural grassland.
\end{abstract}

Key Words: disturbance, Pampa biome, pasture management, resistance to invasion

\section{Introduction}

The invasion of pastoral habitats by allochthonous plants is a global problem, with drastic consequences to the ecological, economic and social systems. The invasion occurs according to many factors such as climatic regions, disturbance regimes, presence of herbivores and the fluctuation of available resources like water, light, and nutrients in the plant community. In the case of the natural grassland of Rio Grande do Sul, invasion is facilitated by the high frequency of soil gaps, originated by the continuous grazing system (Medeiros et al., 2009). On the gaps, nutrients, water and light available offer favorable conditions for recruitment of endemic plants and allochthonous based on the soil seed bank (Davis et al., 2000). It is believed that these factors are the main causes of invasion of South African lovegrass in the natural grassland in Rio Grande do Sul (Medeiros \& Focht, 2007). Its expansion results from the ingestive behavior of animals under continuous grazing, which, in the best period of growing pasture (Spring), prefer to ingest the native prostrate species with higher nutritional value rather than South African lovegrass (Medeiros et al., 2009). In this condition of selective grazing, the South African lovegrass grows in low competition, producing intense flow of panicles from November to March. Under these conditions, when forage quality starts to diminish in the Summer, the animals attempt to compensate their diet by ingesting South African lovegrass (Medeiros et al., 2009), preferring the panicles, the most palatable part of the adult plant (Reis, 1993). One fraction of the seeds produced falls off the panicle and accumulates in the soil seed bank. The animals ingest another seed fraction, along with the panicles, which is distributed locally by the feces or, in the case of animal transport, invades areas in other regions through the seeds preserved, which are viable for up to 3 days in the feces after ingestion (Lisboa et al., 2009).

The total area of natural grassland occupies $63 \%$ of the Pampa Biome in the Rio Grande do Sul State, Brazil (IBGE, 2004). The last survey showed that its occupation dropped to $23.03 \%$, equivalent to 5 million hectares. The 
native grassland area invaded by South African lovegrass is estimated to be superior to one million hectares (Medeiros et al., 2004). This means that there are 4 million hectares not yet invaded by South African lovegrass. As a result, it is necessary to suggest alternative management strategies, aiming at avoiding the invasion of new areas and ensure conditions for sustainable animal production in these ecosystems. Prevention remains as the best strategy to control invasions, for once present and accumulating seeds in the soil in the new area, their eradication becomes extremely difficult (Mohler, 2001).

In view of the above, the effect of sowing South African lovegrass was tested on a natural grassland area subjected to three types of disturbance at three levels of intensity with the objective of generating a diversity of vegetation structures such as pasture height, forage mass and canopy intercepted radiation, capable of avoiding the recruitment of the invader species.

\section{Material and Methods}

The experiment was carried out at the Upacarai homestead ranch, municipality of Dom Pedrito, Rio Grande do Sul, Brazil, in the Campanha ecoclimatic region, Pampa Biome, from February 2004 to April 2007. The soil was classified as Chernossolo Argilúvico Órtico Vértico (EMBRAPA, 2006), corresponding to Chernozems (FAO, 2008), a Ponche Verde mapping unit (Streck et al., 2002). The central geographic coordinates of the experimental site are $31^{\circ} 09^{\prime} 38^{\prime \prime} \mathrm{S}$ and $54^{\circ} 57^{\prime} 29^{\prime \prime} \mathrm{W}$, with average altitude of $140 \mathrm{~m}$. According to the Köppen classification, the climate is Cfa type (Trewartha \& Horn, 1980). The annual average precipitation is $1430 \mathrm{~mm}$, with frequent water deficit in the Summer (Moreno, 1961). The average annual temperature is $20.2{ }^{\circ} \mathrm{C}$, and the average temperature of the hottest month is $32.8^{\circ} \mathrm{C}$ and of the coldest month is $9.1{ }^{\circ} \mathrm{C}$. The soil landscape varies from plain, mildly undulated and undulated (Boldrini, 1997). Precipitation was measured at the experimental site using a direct reading pluviometer (Table 1).

The experimental design was a split-split-plot type in complete blocks, with three replicates, in a natural grassland area of $90 \mathrm{~m} \times 90 \mathrm{~m}\left(8100 \mathrm{~m}^{2}\right)$, in an area free of Eragrostis plana Nees (South African lovegrass). The treatments were: 1) grassland management regimes: exclusion; low grazing intensity (rotational grazing), $\pm 10 \mathrm{~cm}$, with average of grassland height recorded in the field of $11.37 \pm 3.7 \mathrm{~cm}$; and high grazing intensity (continuous grazing), $\pm 5 \mathrm{~cm}$, with average of grassland height recorded in the field of
$6.14 \pm 1.69 \mathrm{~cm}$, composing three plots of $30 \mathrm{~m} \times 30 \mathrm{~m}$, separated by wire fences; 2) initial levels of soil disturbance: high grassland, $\pm 10 \mathrm{~cm}$; low grassland, $\pm 5 \mathrm{~cm}$ height; and low grassland with scarified soil, composing three splitplots of $30 \mathrm{~m} \times 10 \mathrm{~m}$; 3) fertilization regimes: phosphorus (two applications of $50 \mathrm{~kg} \mathrm{P}_{2} \mathrm{O}_{5} /$ year) on the form of triple superphosphate with one application in early autumn and one in early spring; nitrogen (three applications of $50 \mathrm{~kg} \mathrm{~N} /$ year), in the form of urea with applications in early spring, late spring and another one in early autumn, in two years in a row; and without fertilization, composing three splitsplit-plots of $2 \mathrm{~m} \times 2 \mathrm{~m}$ (sampling units).

The combination of the three studied treatments (3 management pasture regimes $\times 3$ initial disturbance levels of soil/pasture $\times 3$ fertilization regimes) resulted in 27 different environmental pasture conditions. Thus, the three replications totalized 81 sampling units.

The preparation of the split-plot area to implement the initial height levels of pasture disturbance (low pasture, and low pasture with soil scarification) was done through a twohour-grazing daily with heifers kept fasting for 12 hours until the plots were reduced to around $5 \mathrm{~cm}$. During this preparation, plots were separated by electric fence, which was removed after the initial procedure. To implement the low initial level of pasture disturbance (high pasture), heifers were removed as soon as the pasture height was reduced to around $10 \mathrm{~cm}$.

On the rotational grazing plots, the native pasture height was maintained at $\pm 10 \mathrm{~cm}$ and controlled through periodic animal grazing. The pasture height on these dates was recorded and, on the following day, around 15 heifers were set in the plots to graze for approximately $1 \mathrm{~h} 30 \mathrm{~min}$, and a new pasture height was recorded again. Whenever necessary, the process was repeated until the pasture height was proximal to $10 \mathrm{~cm}$. The pasture height around $5 \mathrm{~cm}$,

Table 1 - Monthly precipitation ( $\mathrm{mm}$ ) recorded at the experimental site during the evaluation period

\begin{tabular}{lcccc}
\hline \multirow{2}{*}{ Month } & \multicolumn{4}{c}{ Year } \\
\cline { 2 - 5 } & 2004 & 2005 & 2006 & 2007 \\
\hline Jan & - & 50 & 193 & 95 \\
Feb & 70 & 2 & 28 & 141 \\
Mar & 25 & 190 & 86 & 332 \\
Apr & 303 & 162 & 138 & 167 \\
May & 205 & 281 & 155 & - \\
Jun & 91 & 170 & 169 & - \\
Jul & 102 & 65 & 76 & - \\
Aug & 54 & 124 & 101 & - \\
Sep & 182 & 185 & 87 & - \\
Oct & 137 & 216 & 55 & - \\
Nov & 145 & 62 & 190 & - \\
Dec & 34 & 52 & 124 & - \\
\hline
\end{tabular}


on the continuous grazing, was maintained, allowing the heifers a free access to the plots through the permanently open fences. On dry periods or when the pasture growth diminished, the animals were taken out of the plots to maintain the intended pasture height.

On the 27 sampling units $(2 \mathrm{~m} \times 2 \mathrm{~m})$ with initial low pasture and 27 sampling units with initial low pasture with soil scarification, the following winter species were sown: $2 \mathrm{~kg} / \mathrm{ha}$ of Trifolium repens L. (white clover); $6 \mathrm{~kg} / \mathrm{ha}$ of Lotus corniculatus L. (birdsfoot trefoil); $25 \mathrm{~kg} / \mathrm{ha}$ Lolium multiflorum Lam. (italian ryegrass) and $4 \mathrm{~kg} / \mathrm{ha}$ of South African lovegrass. On the other 27 sampling units, with initial high pasture, only South African lovegrass was sown.

The seeds of the cultivated species and the South African lovegrass were sown on July 10, 2004. Seeds were distributed by hand, using nylon sieves in order to obtain a uniform sowing. In the following year, on July 22, 2005, $4 \mathrm{~kg} / \mathrm{ha}$ of South African lovegrass seeds were re-sown in all the 81 sampling units. The seeds of South African lovegrass sown, in both years, presented $100 \%$ of purity and $95 \%$ of germination. The second sowing of South African lovegrass was done to ensure a sufficient number of seeds to compensate possible failing seeds due to drought, predation and/or deterioration of the ones sown in the first year. The average weight of thousand seeds utilized in this experiment was $0.23 \mathrm{~g}$. The number of seeds distributed in each sampling unit represented $1740 / \mathrm{m}^{2}$ in each sowing, totalizing 3480 .

The average height of the plant community was recorded through a metallic ruler graduated in centimeters, and 10 readings were recorded in each sampling unit of $2 \mathrm{~m} \times 2 \mathrm{~m}$. The South African lovegrass plant counting was made in a central square of $0.5 \mathrm{~m} \times 0.5 \mathrm{~m}\left(0.25 \mathrm{~m}^{2}\right)$, in the center of the sampling unit, and estimated at $1 \mathrm{~m}^{2}$.

The readings of the photosynthetic active incident (above canopy) and intercepted radiation at soil level were recorded using an ACCUPAR ceptometer, and the results were presented in radiation interception percentage. The photosynthetic radiations were recorded on October 8, 2006 between $10 \mathrm{AM}$ and $2 \mathrm{PM}$. One record of the incident radiation was taken in each sampling unit of $2 \mathrm{~m} \times 2 \mathrm{~m}$ (split-split-plot) and, within the sward, three records were taken in order to obtain an average value of the intercepted radiation corresponding to that sample unit. The reading bar radiation within the sward was set as close as possible to the soil level.

The mass evaluation of the aerial forage was performed after cutting the pasture at the soil surface in squares of $0.5 \mathrm{~m} \times 0.5 \mathrm{~m}\left(0.25 \mathrm{~m}^{2}\right)$, located in the center of the sampling unit. The botanical separation was carried out in laboratory and the following herbage components were weighed: South African lovegrass, native species and dead + senescent material connected to the plants (Heringer \& Jacques, 2002). After this separation, the samples were dried in forced-ventilation oven at $65^{\circ} \mathrm{C}$ during 72 hours.

The software Assistat (version 7.6) beta for Windows was used to proceed the data variance analysis (ANOVA) and, to compare the means, the Tukey test was used. Pearson correlations were calculated using the software BIOESTAT (version 5) for Windows.

\section{Results and Discussion}

The nitrogen and phosphorus fertilization regimes, on the levels and frequencies used in this experiment, did not influence $(\mathrm{P}>0.05)$ the number of South African lovegrass on the native pasture. The absence of response in relation to the isolated nitrogen application, in the first year, can be explained by the dry spell recorded in August, 2004 soon after sowing, and the long dry spell in December, 2004, January and February, 2005 (Table 1). The response of fertilizers, such as nitrogen on the native pasture, depends on the environmental conditions and resources such as the water availability and temperature (Nabinger et al., 2009). On the second sowing of South African lovegrass, performed in the following year (July 22, 2005), although the water conditions were not too limited, no effect $(\mathrm{P}>0.05)$ of nitrogen fertilization upon the number of South African lovegrass (Table 2) was recorded as well. According to Bemhaja et al. (1994), continued applications of nitrogen in favorable environmental conditions increased forage production due to alterations in the structure and the botanical composition of the grass species on the pasture. Palma et al. (2008) observed that applications of doses of $100 \mathrm{~kg} / \mathrm{ha}$ of nitrogen increased the forage production and grasses frequency. In reason of that, the absence of response in the number of plants of South African lovegrass can be attributed to a dry spell in August 2004, July 2005, and due to the intense effects of levels of soil disturbance and pasture management regimes that may have overlapped the effects of nitrogen fertilization. The response of the isolated phosphorus application to promote alterations in the species frequency was expected, especially in presence of nitrogen. Maraschin (2009) reported alterations in the botanical composition of the native pasture in response to the phosphorus applications. This author emphasized that the applications of phosphorus with lime on native pasture altered the botanical composition and, generally, increase the frequency of legumes such as Desmodium incanum DC. 
It is worth remarking, however, that these responses were slow, especially in soils poor in nitrogen. Because of that, there was not sufficient time for the effect of phosphorus to promote the increase in the number of established South African lovegrass plants. The two other factors, pasture management regimes and initial levels of soil disturbance, due to their characteristics, contributed intensively to the establishment of South African lovegrass, possibly masking the effect of phosphorus (Maraschin, 2009) and nitrogen (Bemhaja et al., 1994).

In relation to the two others factors, on the contrary, interaction effect of the pasture between management regimes and initial level of soil disturbance on the number of South African lovegrass plants was recorded $(\mathrm{P}<0.05)$.

It was verified that the more intense initial level of disturbance in the native pasture favored the recruitment and development of the South African lovegrass in all grazing regimes. The higher number of plants $/ \mathrm{m}^{2}$ recorded in the sampling units under continuous management regime, to maintain the native pasture at a lower height (Table 2), turns it more susceptible to invasion. The lowest number of plants $/ \mathrm{m}^{2}$ was recorded in the exclusion regime (Table 2), which, in opposition to the continuous grazing, favored the growth and the elevation height of the South African lovegrass and other species present in the area (Table 3), making the vegetation environment unfavorable to the recruitment of South African lovegrass. In the rotational grazing, the number of plants of South African lovegrass was intermediate in relation to the other management regimes. In the conditions of levels of soil disturbance, with high and low initial pasture, the South African lovegrass in the three management regimes studied was not recorded (Table 2).

Table 2 - Number of plants of South African lovegrass $/ \mathrm{m}^{2}$ under pasture management regimes and initial levels of soil disturbance on September 27, 2005 and April 30, 2007

\begin{tabular}{|c|c|c|c|c|}
\hline \multirow{2}{*}{$\begin{array}{l}\text { Pasture } \\
\text { management regimes }\end{array}$} & \multicolumn{3}{|c|}{ Initial levels of soil disturbance } & \multirow[b]{2}{*}{ Mean } \\
\hline & $\begin{array}{l}\text { High } \\
\text { pasture }\end{array}$ & $\begin{array}{c}\text { Low } \\
\text { pasture }\end{array}$ & $\begin{array}{l}\text { Low pasture with } \\
\text { soil scarification }\end{array}$ & \\
\hline \multicolumn{5}{|c|}{ September 27, 2005} \\
\hline Exclusion & $0.0 \mathrm{aB}$ & $0.0 \mathrm{aB}$ & $5.8 \mathrm{bA}$ & 1.9 \\
\hline Rotational grazing & $0.0 \mathrm{aB}$ & $0.0 \mathrm{aB}$ & $12.0 \mathrm{abA}$ & 4.0 \\
\hline Continuous grazing & $0.0 \mathrm{aB}$ & $0.0 \mathrm{aB}$ & $13.8 \mathrm{aA}$ & 4.6 \\
\hline Mean & 0.0 & 0.0 & 10.53 & \\
\hline \multicolumn{5}{|c|}{ April 30, 2007} \\
\hline Exclusion & $0.0 \mathrm{aA}$ & $0.0 \mathrm{aA}$ & $16.9 \mathrm{bA}$ & 5.63 \\
\hline Rotational grazing & $0.0 \mathrm{aB}$ & $0.0 \mathrm{aB}$ & 27.6abA & 9.19 \\
\hline Continuous grazing & $9.8 \mathrm{aB}$ & $10.7 \mathrm{aB}$ & $42.2 \mathrm{aA}$ & 20.89 \\
\hline Mean & 3.26 & 3.56 & 28.89 & \\
\hline
\end{tabular}

Means followed by same lowercase and capital letters in the column and in the row, respectively, do not differ by Tukey's test at $5 \%$ of probability.
The low pasture height, initially imposed by the intensive grazing (Table 3 ) and subsequently maintained by the continuous grazing, favored the recruitment of South African lovegrass plants. Many plantlets of South African lovegrass were recruited in the sampling units where disturbance was more intense (low pasture) due to the higher availability of resources, during the spring of 2004, soon after the first seed sowing (July 10, 2004). A water deficit spell, soon after, damaged the germination and the plant establishment of South African lovegrass under the regime of continuous grazing versus high and low initial pasture levels. It was considered that the higher soil cover, in these treatments, may have occasionally prevented available resources from being utilized for the recruitment of plantlets of the invader species.

In the last survey of recruitment of South African lovegrass, on April 30, 2007, interaction effect $(\mathrm{P}<0.05)$ between pasture management regimes and the initial levels of soil disturbance was also recorded. The data showed an increase in the number of invader plants in the sampling units subjected to the most intensive initial level of soil disturbance (scarification), in relation to the number recorded at the same level of disturbance on September 27, 2005 (Table 2), in the three pasture management regimes. It was verified that the continuous management regime facilitated the South African lovegrass plant recruitment in all levels of disturbance. The effect of the continuous pasture management practice reduces the vegetation height (Table 3), creates soil gaps and allow resources not utilized by the resident plants to be available, making the environmental vegetation susceptible to invasion.

Table 3 - Vegetation height $(\mathrm{cm})$ of the native pasture under management regimes and initial levels of soil disturbance on September 27, 2005 and April 30, 2007

\begin{tabular}{lcccr}
\hline \multirow{2}{*}{$\begin{array}{l}\text { Pasture } \\
\text { management regimes }\end{array}$} & $\begin{array}{c}\text { Initial levels of soil disturbance } \\
\text { pasture }\end{array}$ & $\begin{array}{c}\text { Low } \\
\text { pasture }\end{array}$ & $\begin{array}{c}\text { Low pasture with } \\
\text { soil scarification }\end{array}$ & \\
\cline { 2 - 4 } Mean & & \\
Exclusion & $19.4 \mathrm{aA}$ & $20.7 \mathrm{aA}$ & $22.0 \mathrm{aA}$ & 20.68 \\
Rotational grazing & $11.2 \mathrm{bA}$ & $11.7 \mathrm{bA}$ & $12.5 \mathrm{bA}$ & 11.80 \\
Continuous grazing & $6.2 \mathrm{cA}$ & $5.7 \mathrm{cA}$ & $5.6 \mathrm{cA}$ & 5.82 \\
Mean & 12.26 & 12.69 & 13.36 & \\
& \multicolumn{4}{c}{ April 30,2007} \\
Exclusion & $41.1 \mathrm{aB}$ & $36.8 \mathrm{aB}$ & $61.9 \mathrm{aA}$ & 46.59 \\
Rotational grazing & $12.7 \mathrm{bA}$ & $14.3 \mathrm{bA}$ & $12.1 \mathrm{bA}$ & 13.01 \\
Continuous grazing & $8.0 \mathrm{bA}$ & $7.0 \mathrm{bA}$ & $5.9 \mathrm{bA}$ & 7.00 \\
Mean & 20.57 & 19.37 & 26.62 & \\
\hline
\end{tabular}

Means followed by same lowercase and capital letters in the column and in the row, respectively, do not differ by Tukey's test at $5 \%$ of probability. 
Compared with the first evaluation (September 27, 2005), the pasture regime exclusion recorded the lowest number of South African lovegrass plants in relation to two other management regimes. In this evaluation (April 30, 2007), the number of plants of South African lovegrass $/ \mathrm{m}^{2}$ was higher than the one recorded on September 27, 2005 (Table 2). An important effect recorded on the survey conducted on April 30, 2007 refers to the emerging of South African lovegrass in the continuous grazing regime also on the less intense initial soil disturbance (high and low initial pasture), which did not occur in the first survey (Table 2). But no plants of the species were recorded to the same levels of disturbance on the exclusion and rotational regimes. The absence of records of the invader species, in the treatments described above, was explained by the types of disturbance applied when the experiment was started (high and low pasture) and by the maintenance of higher major average pasture height imposed by the rotational and exclusion regimes (Table 3 ). It was proved once again that the invasions recorded at the levels of low pasture and low pasture with soil scarification are directly associated with the low pasture height initially imposed by intense pasture grazing and, subsequently, maintained by continuous grazing. The combination of these two treatments, continuous grazing regime versus high soil disturbance intensity, as expected, contributed to recruitment of South African lovegrass. Therefore, the time elapsed between the first (July 10, 2004) and the second (July 22, 2005) sowing of South African lovegrass was sufficient for some seeds to have the opportunity to germinate and establish, starting the invasion process on the continuous grazing regime. These results confirmed what has been empirically stated by local farmers involved with animal production in the State of Rio
Grande do Sul: "the intensively grazed pasture (overgrazed pasture) favors invasion of the South African lovegrass".

Another factor that interfered in the recruitment of South African lovegrass because of pasture management regimes and initial levels of disturbance was forage dry mass. Statistical difference was recorded $(\mathrm{P}<0.05)$ in each component of forage dry mass. The higher quantity of the component of forage dry mass of South African lovegrass (FDMAL) was produced where the initial level of disturbance was more intense, regardless of the pasture management regime (Table 4). The higher value of FDMAL obtained in the exclusion management regime was due to the fact that South African lovegrass grows in a lower initial competition environment due to absence of grazing. In this case, the establishment of South African lovegrass was favored by higher availability of resources (nutrients, water and light) when soil gaps appear on the native pasture, promoted by intense soil initial disturbance (Mohler, 2001). In the pasture management regimes of exclusion and rotational grazing versus initial levels of soil disturbance low and high initial pasture -, no presence of South African lovegrass was detected and, in consequence, no production of FDMAL was recorded (Table 4). However, the FDMAL at the same levels of disturbance in the continuous grazing regime did not differ from the values recorded in the exclusion and rotational grazing regimes. In view of that, it was observed that exclusion and rotational grazing regimes versus levels of disturbance low and high initial pasture caused unfavorable environmental conditions to the South African lovegrass recruitment due to pasture subsequent greater heights in relation to the heights recorded in the continuous pasture regime. Lower values of forage dry mass of the native pasture (FDMNP) were recorded at the

Table 4 - Mean values of forage dry mass (t/ha) of pastures recorded in evaluation performed on December 10, 2006 under management pasture regimes and initial levels of soil disturbance ${ }^{1}$

\begin{tabular}{|c|c|c|c|c|c|}
\hline $\begin{array}{l}\text { Initial level of } \\
\text { disturbance }\end{array}$ & $\begin{array}{c}\text { South African } \\
\text { lovegrass }\end{array}$ & Native pasture & $\begin{array}{c}\text { South African lovegrass }+ \\
\text { native pasture }\end{array}$ & $\begin{array}{c}\text { Dead }+ \text { senescent } \\
\text { material }\end{array}$ & $\begin{array}{c}\text { Total forage } \\
\text { dry mass }\end{array}$ \\
\hline \multicolumn{6}{|c|}{ Continuous regimes } \\
\hline High pasture & $0.05 \mathrm{~b}$ & $0.92 \mathrm{bc}$ & $0.97 \mathrm{c}$ & $1.06 \mathrm{~d}$ & $2.03 \mathrm{~d}$ \\
\hline Low pasture & $0.02 b$ & $0.71 \mathrm{bc}$ & $0.72 \mathrm{c}$ & $1.10 \mathrm{~d}$ & $1.82 \mathrm{~d}$ \\
\hline Low pasture + soil scarification & $1.10 \mathrm{a}$ & $0.59 \mathrm{bc}$ & $1.69 \mathrm{bc}$ & $1.18 \mathrm{~d}$ & $2.87 \mathrm{~cd}$ \\
\hline \multicolumn{6}{|c|}{ Rotational regimes } \\
\hline High pasture & $0.00 \mathrm{~b}$ & $1.80 \mathrm{abc}$ & $1.80 \mathrm{bc}$ & $3.47 \mathrm{bc}$ & $5.27 \mathrm{bc}$ \\
\hline Low pasture & $0.00 \mathrm{~b}$ & $1.35 \mathrm{abc}$ & $1.35 \mathrm{bc}$ & $3.06 \mathrm{~cd}$ & $4.40 \mathrm{~cd}$ \\
\hline Low pasture + soil scarification & $1.46 \mathrm{a}$ & $0.49 \mathrm{c}$ & $1.95 \mathrm{bc}$ & $2.08 \mathrm{~cd}$ & $4.03 \mathrm{~cd}$ \\
\hline \multicolumn{6}{|c|}{ Exclusion regimes } \\
\hline High pasture & $0.00 \mathrm{~b}$ & $2.51 \mathrm{a}$ & $2.51 \mathrm{ab}$ & $5.40 \mathrm{ab}$ & $7.91 \mathrm{ab}$ \\
\hline Low pasture & $0.00 \mathrm{~b}$ & $2.52 \mathrm{a}$ & $2.52 \mathrm{ab}$ & $6.01 \mathrm{a}$ & $8.53 \mathrm{a}$ \\
\hline Low pasture + soil scarification & $1.86 \mathrm{a}$ & $1.95 \mathrm{ab}$ & $3.80 \mathrm{a}$ & $6.13 \mathrm{a}$ & $9.93 \mathrm{a}$ \\
\hline
\end{tabular}

Means followed by same lowercase letters in the column do not differ by Tukey's test at $5 \%$ of probability.

${ }^{1}$ Means of 9 sampling units. 
initial levels of most intense soil disturbance (native pasture with soil scarification), under the continuous and rotational grazing pasture regimes, but did not differ $(\mathrm{P}>0.05)$ from the forage mass produced in the exclusion management regime (Table 4). The lower native pasture forage mass recorded in the continuous and rotational pasture regimes, in the most intense disturbance, is attributed to the damages caused to the native species by the soil scarification and, subsequently by competition imposed by greater population of South African lovegrass and the recruitment of pioneer species. The sum of forage dry mass of South African lovegrass + native pasture (FDMAL + NP) responded similarly to the isolated FDMAL. This fact occurred due to the effect of the initial level of intense soil disturbance (low native pasture + soil scarification) that, in conditions of available resources, favored the recruitment and growth of the South African lovegrass. This higher forage dry mass of South African lovegrass can also be explained by its type of growth habit (tussock) associated with its animal rejection due to its high percentage of lignin $(10 \%)$ and neutral detergent fiber (80\%) (Medeiros et al., 2009). The forage dry mass of dead + senescent material bound to the plants (FDMDS) and total forage dry mass (FDMT) were higher in the exclusion management regime, intermediate in the rotational grazing regime and lower in the continuous grazing regime. This response was a direct consequence of the heights established initially to each pasture regime. These differences in dry forage pasture mass are directly related to the recruitment of South African lovegrass, i.e., the invasion of native pasture by this species. According to Mohler (2001), the invasion of unwanted species can be reduced through the action of allelopathic substances as a result of the decomposition process of dead material. In view of that, as the amount of the dead + senescent material expanded, the capacity of the native pasture to resist the invasion of allochthonous species such as South African lovegrass increased. In this research, the higher FDMDS recorded in the rotational grazing and exclusion regimes, in the initial levels of soil disturbance (low and high pasture) diminished the recruitment of the South African lovegrass due to the allelopathic effects (Mohler, 2001). Thus, the higher fractions of forage dry mass, as a whole, qualified the native pasture to resist the process of South African lovegrass invasion. Davis et al. (2000) considered that environments with high forage dry mass, without soil gaps contribute to avoid the invasion by exotic plants.

The origin of the effects discussed so far, promoting or limiting the South African lovegrass recruitment, resulted also from the secondary effects caused by higher or lower radiation interception by the different sward heights imposed by the treatments of pasture management regimes. This effect can be observed in the negative linear regression between the pasture height and the percentage of photosynthetic active radiation intercepted (FARint) by the sward at the soil level. This regression allows us to understand that, as the vegetation height increased, the FARint diminished and, consequently, the lower the number of recruited South African lovegrass plants. For the same reason, it is possible to say that, on the contrary, as the vegetation height diminished, the FARint increased and, consequently, the higher the number of recruited South African lovegrass plants.

In the continuous and rotational grazing regimes higher, negative correlations were recorded between the number of plants of South African lovegrass (NPAL) $(r=-0.4718)$ and the forage dry mass components of the native pasture (FDMNP) $(r=-0.6536)$, i.e., as the native pasture component increased, the presence of South African lovegrass decreased. In the three management regimes, positive correlations between the components FDMAL and the South African lovegrass height $(r=0.7355 ; r=0.7876 ; r=0.42029)$ and the number of plants of the invader species $(0.9613 ; r=0.8726$; e $r=0.8142$ ) were recorded. These correlations indicated that, as the FDMAL, the height and the number of plants of South African lovegrass also increased. The negative correlations between FARint and FDMDS $(r=-0.7203)$ in the rotational grazing, on the contrary, indicated that as the FDMDS increased, the FARint of the soil level reduced

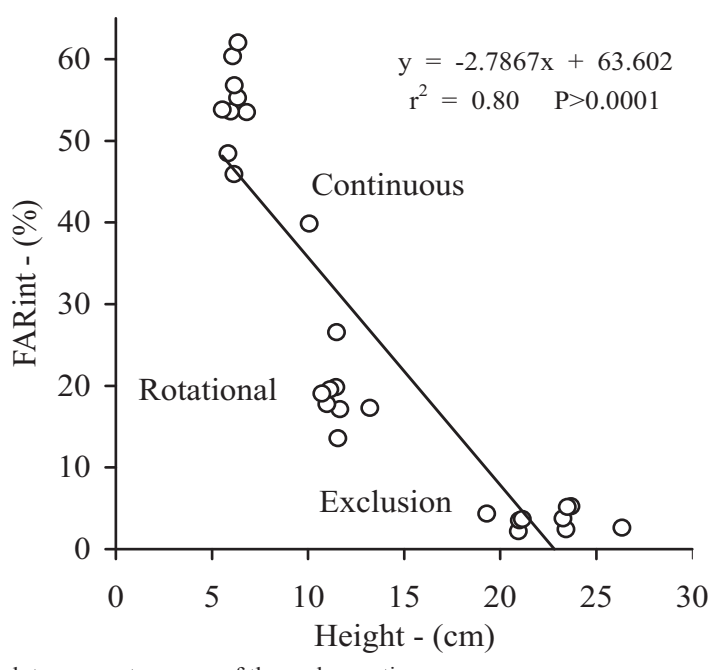

Each dot represents means of three observations.

Figure 1 - Negative linear regression between vegetation height and the percentage of photosynthetic active radiation intercepted (FARint) measured at the soil surface under pasture management regimes at the evaluation on October 8, 2006. 
Table 5 - Pearson correlations (r) between variables of pasture management regimes

\begin{tabular}{|c|c|c|c|}
\hline Dry matter & Height & South African lovegrass (plants $/ \mathrm{m}^{2}$ ) & $\begin{array}{c}\text { Photosynthetic active radiation } \\
\text { intercepted, \% }\end{array}$ \\
\hline \multicolumn{4}{|c|}{ Continuous grazing } \\
\hline Forage dry mass components of native pasture & -0.0932 & -0.4718 & -0.2077 \\
\hline South African lovegrass & 0.7355 & 0.9613 & -0.0585 \\
\hline Probabilities & $<0.0001$ & $<0.0001$ & 0.7721 \\
\hline South African lovegrass + native pasture & 0.7618 & 0.7762 & -0.1954 \\
\hline Probabilities & 0.3848 & 0.7939 & 0.2013 \\
\hline Total forage dry mass & 0.6529 & 0.6063 & -0.2664 \\
\hline Probabilities & 0.0002 & 0.0008 & 0.1719 \\
\hline \multicolumn{4}{|c|}{ Rotational grazing } \\
\hline Forage dry mass components of native pasture & -0.3328 & -0.6536 & -0.2916 \\
\hline Probabilities & 0.0033 & 0.1044 & 0.4150 \\
\hline Dead + senescent material & -0.0543 & -0.4417 & -0.7203 \\
\hline Probabilities & 0.7878 & 0.0210 & $<0.0001$ \\
\hline Total forage dry mass & 0.2479 & -0.1620 & -0.6269 \\
\hline Probabilities & 0.2124 & 0.4193 & 0.0005 \\
\hline \multicolumn{4}{|c|}{ Exclusion grazing } \\
\hline Forage dry mass components of native pasture & -0.1905 & -0.1412 & -0.0664 \\
\hline Probabilities & 0.3412 & 0.4822 & 0.7420 \\
\hline South African lovegrass & 0.4029 & 0.8142 & 0.1264 \\
\hline Probabilities & 0.0371 & $<0.0001$ & 0.1522 \\
\hline South African lovegrass + native pasture & 0.1552 & 0.5277 & 0.0428 \\
\hline Probabilities & 0.4394 & 0.0046 & 0.8321 \\
\hline
\end{tabular}

Data measured on December 10, 2006.

Means of 9 sampling units of disturbance levels.

and, consequently, the probability of South African lovegrass germination and establishment diminished. In the rotational grazing regime, FARint also presented a negative correlation with FDMT $(r=-0.6269)$, reinforcing that the increase of forage dry mass, with greater height, contributed to reduce the probability of South African lovegrass to invade the native pasture.

The continuous grazing regime contributed for some seeds of South African lovegrass to have the chance to germinate and be established, i.e., this management practice, irrespective of the initial level of soil disturbance, was the main factor responsible for the invasion of the native pasture by South African lovegrass. This study confirmed that the maintenance of a larger height of pasture making use of rotational grazing or exclusion may avoid the invasion of South African lovegrass on the native pasture. These results showed that a native pasture above $10 \mathrm{~cm}$ of height, with larger biomass, more dense and vigorous, can maximize the utilization of environmental resources (light, nutrients and water) and, consequently, limit these resources to an eventual recruitment and development of the invader species (Davis et al., 2000). Vegetation communities under this condition sustain larger amounts of green forage mass, accumulate dead and senescent material, eliminate soil open gaps, reduce the light penetration and the soil temperature on the soil surface. Together, these factors induce the allelopathic effect on the superficial soil layer or on South African lovegrass itself (Coelho, 1986; Ferreira et al., 2008), which, according to Mohler (2001), are harmful to seed germination and plant recruitment. On the contrary, the greatest invasion occurred under continuous grazing, regardless of the initial soil disturbance, and it was directly associated with a lower height of the native pasture imposed initially by the intensive grazing and, subsequently, maintained low by continuous grazing. This pasture management regime, as expected, favored the appearance of South African lovegrass plants in any condition of initial soil disturbance, although at the most intensive level 
of disturbance (low pasture with soil scarification), plant recruitment was four times superior to the one observed in the high pasture (Table 2). Thus, in the continuous pasture regime, the time elapsed between the first seed sowing of South African lovegrass (July 10, 2004) and the last evaluation (April 30,2007) was sufficient for some seeds of the invader species to have a chance to germinate and be established, starting the invasion process.

\section{Conclusions}

Ecological management practices are efficient to prevent the invasion of South African lovegrass in the Pampas. The rotational grazing system, which maintains the native pasture residue, with a height near $10 \mathrm{~cm}$, enables the development of a dense and vigorous pasture biomass that, in consequence, limits the available environmental resources to the recruitment of South African lovegrass. The continuous grazing system, that maintains the native pasture residue with a height near $5 \mathrm{~cm}$, facilitates the invasion of a population of South African lovegrass, which utilizes the available environmental resources. Under this management system, the native pasture has lower height, is less dense, and has a lower biomass. The exclusion of the animals from native pasture, regardless of the initial level of disturbance, allows the development of a high, dense and vigorous biomass, which can limit the available environmental resources to the recruitment of South African lovegrass.

\section{Acknowledgements}

The authors thank to Sindicato Rural de Dom Pedrito and Estância Guatambu for the logistic and financial supports; EMBRAPA, CNPq and CAPES for the fellowship received by first author.

\section{References}

BEMHAJA, M.; BERRETA, E.J.; BRITO, G. Respuesta a la fertilización nitrogenada de campo natural en basalto profundo. In: REUNIÓN DEL GRUPO TÉCNICO REGIONAL DEL CONO SUR EN MEJORAMIENTO Y UTYILIZACIÓN DE LOS RECURSOS FORRAJEROS DEL ÁREA TROPICAL E SUBTROPICAL - GRUPO CAMPOS, 14., 1994, Tacuarembó, Uruguay. Anais... Tacuarembó: Instituto Nacional de Investigacion Agropecuaria, 1994. p.211-212.

BOLDRINI, I.I. Campos do Rio Grande do Sul: caracterização fisionômica e problemática ocupacional. Boletim do Instituto de Biociências, n.56, p.1-39, 1997.

COELHO, R.W. Substâncias fitotóxicas presentes no capim-annoni-2. Pesquisa Agropecuária Brasileira, v.21, n.3, p.255-263, 1986.

DAVIS, M.A.; GRIME, J.P.; THOMPSON, K. Fluctuating resources in plant communities: a general theory of invasibility. Journal of Ecology, v.88, p.528-534, 2000.
FAO/IIASA/ISRIC/ISS-CAS/JRC. Harmonized world soil database (version 1.2). Rome: FAO; Laxenburg: IIASA, 2012.

FERREIRA, N.R.; MEDEIROS, R.B.; SOARES, G.L.G. Potencial alelopático do capim-annoni-2 (Eragrostis plana Nees) na germinação de de sementes de gramíneas perenes estivais. Revista Brasileira de Sementes, v.30, n.2, p.43-53, 2008 .

HASENACK, H.; CORDEIRO, J.L.P.; COSTA, B.S.C. Cobertura atual do Rio Grande do Sul. In: Sustentabilidade produtiva no Bioma Pampa. In: SIMPÓSIO DE FORRAGEIRAS E PRODUÇÃO ANIMAL, 2., 2007, Porto Alegre. Anais... Porto Alegre: Departamento de Plantas Forrageiras e Agrometeorologia/UFRGS, 2007. p.15-22.

HERINGER, I.; JACQUES, A.V.A. Composição florística de uma pastagem natural submetida a queima e manejos alternativos. Ciência Rural, v.23, n.2, p.315-321, 2002.

INSTITUTO BRASILEIRA DE GEOGRAFIA E ESTATÍSTICA - IBGE. Anuário da pecuária brasileira. São Paulo, 2004. 376p.

LISBOA, C.A.V.; MEDEIROS, R.B.; AZEVEDO, E.B. et al. Poder germinativo de sementes de capim-annoni-2 (Eragrostis plana Nees) recuperadas em fezes de bovinos. Revista Brasileira de Zootecnia, v.38, n.3, p.405-410, 2009.

MARASCHIN, G.M. Manejo do campo nativo, produtividade animal, dinâmica da vegetação e adubação em pastagens nativas do Rio Grande do Sul. In: PILLAR, V.D.P.; MÜLLER, S.C.; CASTILHOS, Z.M. et al. (Eds.) Campos Sulinos - conservação e uso sustentável da biodiversidade. Brasília: Ministério do Meio Ambiente, 2009. p.248-259.

MEDEIROS, R.B.; FOCHT, T. Invasão, prevenção, controle e utilização do capim-annoni-2 (Eragrostis plana Nees) no Rio Grande do Sul, Brasil. Pesquisa Agropecuária Gaúcha, v.13, n.1, p.105-114, 2007.

MEDEIROS, R.B.; PILLAR, V. D.; REIS, J.C.L. Expansão de Eragrostis plana Ness (capim-annoni-2), no Rio Grande do Sul e indicativos de controle. In: REUNIÓN DEL GRUPO TÉCNICO REGIONAL DEL CONO SUR EN MEJORAMIENTO Y UTYILIZACIÓN DE LOS RECURSOS FORRAJEROS DEL ÁREA TROPICAL Y SUBTROPICAL - GRUPO CAMPOS, 20., 2004, Salto, Uruguay, 2004. Memorias... Salto: Regional Norte de la Universidad de la República, 2004. v.1, p.211-212.

MEDEIROS, R.B.; SAIBRO, J.C.; FOCHT, T. Invasão do capim-annoni (Eragrostis plana Nees) no bioma Pampa do Rio Grande do Sul. In: PILLAR, V.D.P.; MÜLLER, S.C.; CASTILHOS, Z.M. et al. (Eds.). Campos Sulinos - conservação e uso sustentável da biodiversidade. Brasília: Ministério do Meio Ambiente, 2009. p.317-330.

MENDONÇA, J.F.B. Solo: substrato da vida. Brasília: Embrapa Recursos Genéticos e Biotecnologia, 2006. 156p.

MOHLER, C.L. Weed evolution and community structure. In: LIEBMAN, M.; MOHLER, C.L.; STAVER, C.P. (Eds.) Ecological management of agricultural weeds. Cambridge: Cambridge University Press, 2001. p.444-493.

MORENO, J.A. Clima do Rio Grande do Sul. Porto Alegre: Secretaria da Agricultura, 1961. 41p.

NABINGER, C; FERRREIRA, E.T.; FREITAS, A.K. et al. Produção animal com base no campo nativo: aplicações e resultados de pesquisa. In: PILLAR, V.D.P.; MÜLLER, S.C.; CASTILHOS, Z.M. et al. (Eds.). Campos Sulinos - conservação e uso sustentável da biodiversidade. Brasília: Ministério do Meio Ambiente, 2009. p.175-198.

PALMA, R.R.; RODRÍGUEZ, T.; ANDIÓN, J. et al. Fertilización de campo natural: respuesta en produción de forraje. In: REUNIÃO DO GRUPO TÉCNICO EM FORRAGEIRAS DO CONE SUL GRUPO CAMPOS, 22., 2008, Minas, Uruguay. Anais... Minas: INIA, 2008. p.197-198.

REIS, J.C.L. Capim annoni-2: Origem, morfologia, características, disseminação In: REUNIÃO REGIONAL DE AVALIAÇÃO DE PESQUISACOMANNONI-2, 1991, Bagé. Anais... Bagé: EMBRAPACPPSUL, 1993. p.5-23. (EMBRAPA-CPPSUL. Documentos, 7).

STRECK, E.V.; KÄMPF, N.; DALMOLIN, R.S.D. et al. Solos do Rio Grande do Sul. Porto Alegre: EMATER/RS; UFRGS, 2002. 126p.

TREWARTHA, G.T.; HORN, L.H. Koppen's classification of climates. In: An introduction to climate. New York: McGraw-Hill, 1980. p.397-403. 